\title{
Builders' Perceptions of Lowest Cost Procurement and its Impact on Quality
}

\author{
Mary Hardie and Swapan Saha (School of Engineering, University of Western Sydney, Australia)
}

\begin{abstract}
The concept of quality in relation to a product or service refers to the degree to which it meets the customer's needs and expectations. Dissatisfaction with the quality of building projects has been widely reported in recent times. There are indications that there may be some relationship between the procurement method used and customer satisfaction with the delivered product. In particular, traditional competitive bid contracting may have an adverse impact on quality in some circumstances. To shed some light on reported industry attitudes, a survey of construction professionals in the Sydney metropolitan area was undertaken. The respondents demonstrate mixed views on the effectiveness of the competitive tender system on quality project outcomes. To some extent contractors' attitudes may be determined by their preferred current mode of operation. However, some support is expressed for the contention that quality of outcome can be reduced by an overly cost driven contractor selection process. In particular, when economic pressures cause bidders to reduce the time allocated for the tender process, an inaccurate and unreliable bid may win. This makes it very difficult for the reliable contractor to remain profitable. A move to value-based rather than cost-based procurement may assist industry performance and customer satisfaction.
\end{abstract}

Keywords: procurement, quality, builders' perceptions, tender process, Sydney.

\section{INTRODUCTION}

Traditional contractor selection in the construction industry in Australia and elsewhere has long been managed through the process of calling for competitive cost-based tenders as the principal means of allocating projects. This procurement method is sometimes described as 'design-bid-build'. Such bidding processes may also include estimated construction time as an additional selection component but, in general, they do not include an assessment of the contractor's ability to deliver quality project outcomes (Cartlidge, 2004; Masterman, 2002; Rowlinson and McDermott, 1999). Consequently, the lowest priced tenderer may not ultimately be able to deliver the best value for the project's end users. The traditional system attempts to manage quality either by the exclusion of all but known or 'invited' tenderers or by independent supervision of the contractor's work by an architect or other expert.

There are potential difficulties with both options. As several authors identify, in the former case of invited tenders or pre-qualification, there is a risk of a 'closed shop' situation developing where new contractors are locked out of the process (Fong and Choi, 2000; Mahdi et al., 2002; Ng et al., 1999; Palaneeswaran and Kumaraswamy, 2001). In the latter case of architect supervision there may be either a lack of expertise in 'buildability' issues or insufficient resources and availability to make timely decisions on problems that arise on site (Yates and Battersby, 2003).
As a result of these problems over several decades, the industry has seen a gradual increase in the use of other procurement methods such as design and construct, in-house development, partnering and relationship contracting (Arditi and Lee, 2003; Bresnen and Marshall, 2000; Chan et al., 2003). Nevertheless, the traditional competitive tender system has not disappeared. Despite evidence of the system's shortcomings, owners sometimes see competitive prices as their only significant way of ensuring some market input into the procurement of an expensive asset. It is not possible to 'comparison shop' for new buildings in quite the same way as it is for real estate. Competitive tendering gives the impression of fulfilling this role although it may not necessarily always deliver a successful outcome. Builders can favour competitive tendering because it allows them to specialise in the delivery of projects and avoid involvement in design iterations and project approval processes. Whatever the procurement method the relationship between cost and value remains a problematic one. In general, the competitive bidding process emphasises cost at the expense of value and the result is a widely reported problem with delivering project quality in the traditional system (Uher, 1999; Walker and Hampson, 2003; Hampson, 2005).

The purpose of this paper is to explore perceptions of lowest cost procurement and its impact on quality. A survey of construction professionals in the Sydney metropolitan area is investigated to address this question and formulate recommendations.

\section{COST VERSUS VALUE IN CONSTRUCTION PROJECTS}

Client satisfaction with the outcome of a building project is identified as having three parameters that relate to the value triangle (see Figure 1). These are: final project cost compared to the budget; timely project delivery; and quality of the built project result. The quality parameter is particularly difficult to judge in construction because the customer's decision to buy is based on the concept of a product rather than on the demonstrated finished product as is the case in most industries. Some people have limited visual literacy and have difficulty understanding the end result from design drawings. A client who has difficulty visualising the completed project may cling to cost assessment as something that can be counted on. If cost overruns occur for whatever reason, the client's satisfaction level is likely to rapidly decline, even if the cost increases are caused by the failure to accurately specify needs or to understand documentation.

This problem particularly applies to inexperienced and 'one-off' clients. Large repeat clients such as government and semigovernment bodies are less likely to suffer from such shortcomings (Manley, 2006). The public sector in Australia, however, represents less than a quarter of the non-residential construction industry and the private sector is varied and contains numerous very small players (ABS, 2007). The influence of large repeat clients is therefore considerably less than in more centralised economies such as Singapore or Hong Kong. 


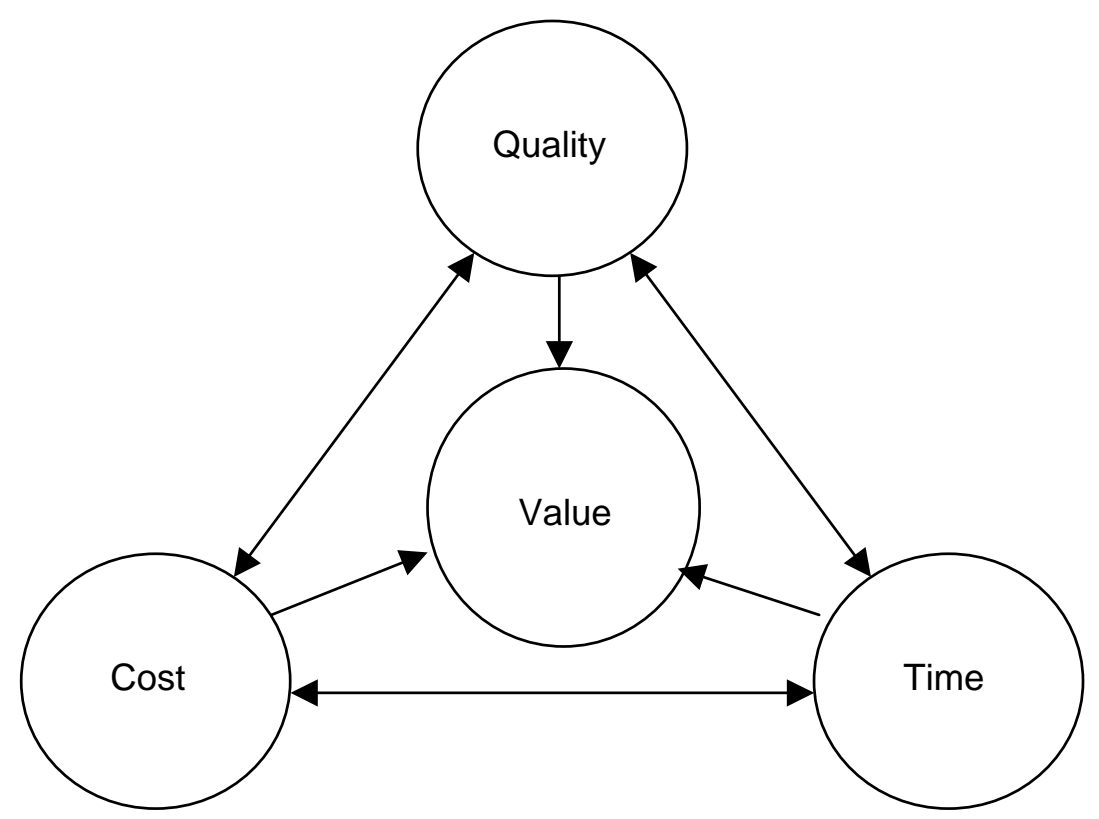

Figure 1: Cost-time-quality: the value triangle

Of course, contractual arrangements can be used to manage potential price escalation during the project, but these arrangements sometimes result in protracted legal battles when a bid has been inadequately prepared or when unforeseen issues arise during the construction period for any reason. An inexperienced owner may not be aware of the potential pitfalls inherent in the complexity of construction project delivery. The lowest tender price from several contractor bids will loom large in the assessment of such an owner because it is easily ranked in a way that delivered quality is not. Similarly, estimated construction time is easily ranked but the veracity of the estimate may be hard for an owner to judge.

The competitive bidding process often places the prime contractor and the owner in adversarial positions, a situation which can lead to undesirable outcomes for project quality (Langford et al., 2007). The result is that competitive bidding can lead to the selection of incompetent contractors, excessive variations to contracts, litigation and protracted disputes. It can also be one of the constraining factors for the application of quality management principles (Abdul-Aziz, 2002). Experienced clients have in many parts of the world managed to use their market share and expertise to develop systems to overcome this problem by using performance-driven procurement methods (Coffey, 2008). The issue remains a significant one in the more diversified commercial economies.

The issue of the technical competence of construction clients to assess tenders was pointed out as a problem as far back as Bowley's seminal study of the UK construction industry in the 1960s (Bowley, 1966). It has received further research attention in recent times (e.g. Manley, 2006). While large government departments and large commercial clients may develop in-house expertise at assessing construction tenders over a series of similar projects, the one-off client has no opportunity to do this and is unlikely to be able to adequately compare tenders from contractors with differing levels of expertise and experience. If a contractor has made a mistake in preparing the estimate or has deliberately underpriced it in order to win a contract in the hope of future work, the inexperienced client will probably not detect the problem until it is too late to effectively make another contractor selection.

\section{IDENTIFICATION OF CLIENT NEEDS}

A further issue with the process involved in design-bid-build procurement can be the problem of clearly identifying and quantifying the client's needs (Arditi and Lee, 2003). In the traditional system the brief making process is carried out by the owner and the designer with little or no involvement from the builder. This is not a problem for many projects but can create difficulty when the proposed building is unusual or bespoke and solutions are proposed that require new construction methods or practices. Several researchers point out the critical need to get the briefing process right in order to deliver a good project result (London et al.,2005; Yu et al., 2008; Smith et al., 2008).

The quantifiable aspects of formulating a brief include floor areas, spatial relationships, service requirements and performance standards. The qualitative aspects are even more problematic as they include concepts of image, aesthetics and human comfort expectations. There are few endeavours where a customer agrees to pay for something when they necessarily have limited knowledge of exactly how the final product will turn out. This disparity between the customer's identified needs and the specific built solution provided is posited as one of the main sources of customer dissatisfaction with buildings.

Research identifies a lack of customer focus in the construction industry (Dulaimi, 2005). Many building contractors see themselves as supplying a product according to predetermined specifications and costs and they put little effort into understanding what the customer actually wants or expects from their project. This matter is further complicated when the end users of the building are not the same as the owners or the customer/client who procures the building. Builders who identify repeat business as an important source of ongoing prosperity, of course, recognise the importance of good client relationships and of ensuring that the end users find the delivered product satisfactory. Soetanto and Proverbs (2002) note this in their study of contractors' assessments of client performance. Reputation and 'word of mouth' recommendations of former clients are a valuable marketing tool that can enable them to survive economic downturns and manage continuous work streams in a disjointed and project-based industry. 
Some builders see the construction industry as a service based activity that responds to client demand rather than creating demand. This is not always so, as Nam and Tatum (1992) have shown that some builders are very successful at developing new technical solutions which lead the market to new performance levels rather than simply responding to what the customer asks for in a standard manner. This raises the issue of how the design-bidbuild procurement can incorporate innovation and new technical development.

\section{INNOVATION}

Innovation as defined by Slaughter (1998) is the successful introduction of new products, processes or equipment. Traditional procurement tends to leave the realm of innovation to the designer and require the builder to simply deliver what has been specified within cost and time parameters. This denies the particular expertise of builders any significant creative input in the project delivery process. There can be non-conforming tenders, of course, where the builder makes suggestions that impact on the designed solution but these tend to mean that the main benefit of design-bidbuild is lost as a market price for the work may not be able to be established through price competition (Sidwell et al., 2001).

Non-conforming tenders present a particular difficulty for the inexperienced client to assess. Like is not being compared with like and a judgement call has to be made on the issue of which prospective solution best suits the client's needs. In general, procurement methods such as partnering and relationship contracting have proven to be better at allowing for the incorporation of innovative solutions than traditional competitive tender procurement (Walker et al., 2003; Walker and Hampson, 2003; Barlow and Jashapara, 1998; Kumaraswamy and Dulaimi, 2001).

\section{BUILDABILITY}

As previously mentioned, contractor input to design is largely missing from competitive tender procurement with a resulting lack of focus on the buildability of the project design (Akintoye, 2000). Architects and building designers have variable levels of training in the technical aspects of construction. Their focus can be exclusively on the finished product with little attention to the sometimes larger issues involved in physical project delivery. This lack of understanding can impact on cost. In addition, problems with the initial design and the documentation presented for a tender can exacerbate the situation (Cox et al., 1999). Comprehensive documentation is difficult to produce for a construction project as there are often many unknowns at the commencement of a project. Consequently quality of documentation has been identified as an issue for the industry as a whole and increasingly there are multiple iterations of project documents even in traditional tender bid projects.

With the complexity of building projects increasing in terms of services, communications and transport interfaces, it is all the more critical that the particular expertise of builders is allowed to have input into the formative phase of a project. Traditional procurement tends to work against this end and the result may be a large amount of rework on site and attendant costs relating to delays, wasted labour and materials (Love et al., 1999).

\section{ADVERSARIALITY}

The final issue of significance with regard to traditional procurement is that it tends to lead to an adversarial relationship between the client and the builder. The client is seeking the cheapest price and the builder is trying to maximise profits. This can lead to the 'variation' game, where any discrepancies, errors or omissions in the documentation are used to increase return to the builder at the owner's expense.

Partnering and alliancing procurement systems seek to solve this problem by sharing both the pain and the gain in project delivery and thereby eliminating adversarial contests between the parties and substituting a 'best for project' criterion for resolving disagreements. This may well present a useful future path for the industry but at the moment, at least in Australia, such 'relationship contracts' are largely the province of big companies and government organisation procurement and have not greatly impacted on procurement at the smaller commercial and residential project level.

\section{RESEARCH SIGNIFICANCE}

Hall and Pearl (2002) identify significant variations in the perceptions about time, cost and quality on building projects. Such perceptions can have impact on project operations particularly by supporting resistance to change. Consequently, it was decided to find out if builders in the local area of the Sydney metropolitan region share the misgivings of academic researchers about the functioning of the competitive tender system of construction procurement. While a study of perceptions has its limitations, it may nevertheless be enlightening in terms of the factors that constrain effective change.

There are commercial, social and environmental reasons for this study. If a relationship exists between procurement method and project quality, it is beneficial for construction companies to know which method of project delivery supports greater quality, in order to ensure maximum positive effect on reputation and repeat business. This information is also important for property investors as the quality of the built property on the market impacts on their investments and returns. The issue is important on a social level as everyone uses the built environment and its quality impacts on the lives of all users. It is also significant for the environment as construction has a major impact on resource and energy usage, and waste generation and each of these has a direct impact on the natural environment.

The research questions to be addressed in this study are whether or not builders have a sense of dissatisfaction with traditional competitive tender procurement and whether or not they believe that procurement systems impact on the quality of their delivered product.

\section{METHODOLOGY}

A survey was created to test reactions to these questions. Initially a pilot survey was developed and was used to canvass three different categories of construction professionals: builders, property developers, and construction managers. Eighteen surveys were sent out evenly distributed between the three different types of construction professionals. Twelve responses were received. Six of these responses were from builders, five responses were from property developers and one only response came from a construction manager. The pilot survey was used to give an estimate of the interest level and a guide to the adequacy of the sampling frame chosen. As a result of the pilot survey, it was decided to only survey builders and developer/builders. Project managers may be at arm's length from the procurement issues under consideration and therefore be less likely to respond to surveys on the topic. The final survey was modified slightly as a result of feedback from the pilot survey respondents. Fifty final 
surveys were sent out, with twenty-five going to builders, and twenty five going to property developer/builders. Participants were identified via their reputation as established participants in the building industry in Sydney. They do not represent a randomised sample but rather a purposive selection of participants known to be engaged with the issues under consideration. As such it is not claimed that the responses represent a rigorous statistical opinion poll of industry attitudes but rather an impression of a range of attitudes from a snapshot of industry participants at a particular time in a particular place.

All the survey participants were the principal of their construction or development company. They ranged between 30 and 60 years of age and they all held either university or technical college qualifications in construction. Twenty-eight completed surveys were received for a response rate of $55 \%$. Twenty-one of the respondents classified themselves as 'builders' and seven classified themselves as 'property developer/builders'. Some respondents came from the commercial building sector, some from residential construction and some operated in both sectors. A large majority (22 respondents or $80 \%$ ) had been in business for more than ten years. $75 \%$ of survey respondents reported that competitive bidding was the main source of work for their organisation.

The survey results are reported in Table 1.

Table 1: Responses to questionnaire

\begin{tabular}{|c|c|c|c|}
\hline Question & & Response & \\
\hline $\begin{array}{l}\text { Which of the following aspects of a project is most } \\
\text { important to your organisation when constructing a } \\
\text { project? } \\
\text { a) Total cost incurred, } \\
\text { b) Time it takes to build; or } \\
\text { c) Quality of the project. }\end{array}$ & a) $100 \%$ & b) $0 \%$ & c) $0 \%$ \\
\hline $\begin{array}{l}\text { Does your organisation mainly award sub-contracts based } \\
\text { on price alone? }\end{array}$ & Yes $0 \%$ & No $100 \%$ & \\
\hline $\begin{array}{l}\text { Has your organisation ever awarded a sub-contract to the } \\
\text { lowest bidder that resulted in an unsatisfactory quality of } \\
\text { work? }\end{array}$ & Yes $35 \%$ & No $65 \%$ & \\
\hline $\begin{array}{l}\text { How do you think shortening a construction schedule in } \\
\text { order to lower the cost of the project impacts the overall } \\
\text { quality of the project? Circle your answer: } \\
\text { a) No impact } \\
\text { b) Small impact } \\
\text { c) Large impact }\end{array}$ & a) $50 \%$ & b) $25 \%$ & c) $25 \%$ \\
\hline $\begin{array}{l}\text { When pricing a project, does your organisation attempt to } \\
\text { lower its bid in order to win the tender? }\end{array}$ & Yes $25 \%$ & No $75 \%$ & \\
\hline $\begin{array}{l}\text { If yes. Has your organisation ever lowered the bid } \\
\text { significantly resulting in a less than satisfactory profit } \\
\text { return? }\end{array}$ & Yes $0 \%$ & No $100 \%$ & \\
\hline $\begin{array}{l}\text { In your opinion, how does awarding a job to the lowest } \\
\text { bidder, as opposed to the more reliable bidder for sub- } \\
\text { contracts, impact the quality of the end project? Circle } \\
\text { your answer: } \\
\text { a) No impact } \\
\text { b) Small impact } \\
\text { c) Large impact }\end{array}$ & a) $0 \%$ & b) $25 \%$ & c) $75 \%$ \\
\hline $\begin{array}{l}\text { In your opinion, do you think that lowering the cost also } \\
\text { lowers the quality of the project? }\end{array}$ & Yes $100 \%$ & No $0 \%$ & \\
\hline $\begin{array}{l}\text { Which of the following do you believe general contractors } \\
\text { strive to achieve most when undertaking a construction } \\
\text { project? Circle your answer: } \\
\text { a) Quality of the product } \\
\text { b) Profit }\end{array}$ & a) $100 \%$ & b) $0 \%$ & \\
\hline $\begin{array}{l}\text { Which of the following do you believe general contractors } \\
\text { normally achieve when a project is finished? Circle one } \\
\text { answer: } \\
\text { a) A quality project } \\
\text { b) A quality project with a satisfactory profit } \\
\text { c) Neither }\end{array}$ & a) $25 \%$ & b) $75 \%$ & c) $0 \%$ \\
\hline $\begin{array}{l}\text { Has your organisation ever completed a project and come } \\
\text { out with unsatisfactory quality according to the client? }\end{array}$ & Yes $25 \%$ & No $75 \%$ & \\
\hline $\begin{array}{l}\text { Do you believe that the traditional competitive bidding } \\
\text { tender procurement method has its problems? }\end{array}$ & Yes $25 \%$ & No $75 \%$ & \\
\hline $\begin{array}{l}\text { Which organisation do you think would strive to achieve } \\
\text { higher quality in a project? } \\
\text { a) General contractor under competitive bidding } \\
\text { procurement method; or } \\
\text { b) General contractor under an alternative } \\
\text { procurement method, which ends with the general } \\
\text { contractor owning the building that they have to } \\
\text { sell. }\end{array}$ & a) $75 \%$ & b) $25 \%$ & \\
\hline
\end{tabular}


All respondents report that the quality of the building project is the most important aspect for their organisation when constructing a building project. No respondents rate time or cost as more important than quality. This is at least partly explained by the phenomenon of 'survey compliance', in that it would have been clear to the participants that this was both the acceptable and the desired response to the survey. Although assurance was given that survey participants would not be identified in any way, it is still likely that respondents would have consideration for the appearance that their response gives of the company and the industry. Similarly, on the question of whether their organisation awards sub-contracts on the basis of price alone, all respondents answered 'No'.

Clearly there is some recognition that cost is not appropriate or sufficient as the sole criterion for determining competence to perform building tasks. This may be stating the obvious but in recent years the philosophy of economic rationalism has led some procurers to rely almost completely on cost as the determining factor for contractor selection for building projects.

On the question of whether their organisation had ever awarded a sub-contract to the lowest bidder resulting in unsatisfactory work, thirty-five percent replied 'yes' and sixty-five percent replied 'no'. In hindsight it would have been advisable to follow this question with one on whether the organisation had ever awarded a sub-contract to a bidder who was not the lowest price bidder and still had unsatisfactory work resulting. This would have been stronger evidence for the lowest cost bid being closely related to unsatisfactory results. As it is we can only say that for a significant percentage of survey respondents the choice of lowest price bidder sometimes results in unsatisfactory work.

There is a mixed response to the question of whether shortening of the construction schedule in order to lower costs has an impact on the quality of the delivered project. Fifty percent say there is no impact. Twenty-five percent say that there is a small impact and twenty-five percent say there is a large impact on quality. Given the caveat that some respondents may have been answering with a view to presenting themselves and their industry in the best light, it is interesting that a quarter of respondents state that shortening the time schedule would have a large impact on the quality of the result. It is evident that the value triangle presented earlier is intrinsically understood to impact on project satisfaction rates. Nevertheless the reported mean assessment of the impact of shortening the schedule lay between 'no impact' and 'small impact'. Developer/builders in the sample rate the likelihood of impact slightly higher than builders did but this is not statistically significant. A larger survey is needed to confirm whether or not this difference is significant.

Respondents with long experience in the industry (over twenty years) were considerably more likely to indicate that the shortening of the schedule would result in lowering of quality. No significant difference was observed between those respondents who mainly undertake competitive bidding and those who mainly initiate their own projects.

Survey respondents were asked whether their organisation ever lowers its bid in order to win a tender. Seventy-five percent of respondents answered 'no'. It may be that some respondents interpreted this question as dealing with unethical collusion or improper negotiation of tender prices. Of course, all estimators will try to get the lowest possible effective price when preparing a tender. The question is unclear about the point in the process where price lowering would take place. All the respondents who replied in the affirmative to this question also said that the lowering of their tender price did not have any impact on the profitability of the project. This suggests that they apply their own standards and priorities to the negotiation of final prices in tenders.

The impact of awarding a tender to the lowest price compared to a more reliable sub-contractor is the subject of the next question. No respondents thought that this would have 'no impact'. Twentyfive percent say it has a 'small impact' and seventy-five percent say that the impact is 'large'. The use of the word 'reliable' seems to be of significance here. Although several builders feel they could lower their own prices without impact, they are wary of sub-contractors whose pricing might not necessarily be 'reliable'. There is an acknowledgment of the perils of lowest cost tendering as inexperience, dishonesty or incompetence may lead to subcontractors overreaching and submitting unachievable prices. This is reinforced by the $100 \%$ affirmative response to the question of whether cost reduction results in decreased quality of projects.

Three quarters of respondents rate profit as the principal goal that they are aiming to achieve in a building project, while one quarter put quality first. A slightly different emphasis is evident in response to the next question on what is generally achieved at the end of a building project with $100 \%$ of answers saying that both a quality product and a satisfactory profit would be achieved.

One quarter of respondents admit having had a project where the quality of the end product was unsatisfactory to the client. This rate is considerably lower than the rate of client dissatisfaction measured elsewhere (Dulaimi, 2005). A larger study may be needed to shed light on this discrepancy. Similarly $75 \%$ of respondents declare that they see no problem with traditional competitive tendering. This contrasts with widespread reports of unsatisfactory results from the system. When asked directly whether higher quality could be achieved via competitive tendering or through another procurement method, the $75 \%$ who work mainly in competitive tendering list that option and the $25 \%$ who operate under other systems chose the 'other procurement method' response. This simply indicates that the contractors surveyed choose to operate in a system that suits them and does not give any objective assessment of how procurement affects project quality.

\section{CONCLUSION}

Although the literature of construction research provides ample information on the shortcomings of competitive tendering as a procurement system, the perceptions of practitioners who operate within the system may be much more mixed (Zaghloul and Hartman, 2006). The builders and developer/builders surveyed for this study are surprisingly supportive of the system as it exists. While this may be partly due to the 'inertia of current practice', it may also be partly due to the fact that competitive tendering still answers the needs of some parts of the industry. It can continue to supply a constant stream of work for the effective operator while giving the owner some reassurance that a market tested price is being paid. Nevertheless there is a continuing likelihood in economic downturns that some contractors will win tenders based solely on price and prove incapable of delivering a quality outcome.

It is likely that in much of industry a truly open call for tenders is rarely made. Effectively there is always a level of vetting or pre-qualification to ensure the worst potential problems with the bidding system are avoided. This may not be done formally but rather through a greater reliance on informally invited rather than open tenders. Competitive tendering is likely to remain a part of the 
suite of procurement methods used for building projects despite the growth in the various forms of design-build and/or relationship contracting. The impact of using cost as the only parameter for contractor selection, however, needs to be modified by inclusion of the other considerations which affect satisfaction with the end project. Quality of the delivered end product is not entirely dependent on cost but neither is it desirable to leave cost out of the assessment equation.

The value triangle has three corners and each must be addressed in some way in the evaluation of potential contractors for building projects.

\section{ACKNOWLEDGEMENTS}

The authors wish to acknowledge the assistance of Professor Alan Jeary and construction student Lee Salvaggio in the preparation of this research.

\section{REFERENCES}

Abdul-Aziz, A.-R. (2002) 'The realities of applying total quality management in the construction industry', Structural Survey, 20(2), 88-96.

Akintoye, A. (2000) 'Analysis of factors influencing project cost estimating practice', Construction Management and Economics, 18(1), 77-89.

Arditi, D. and Lee, D.-E. (2003) 'Assessing the corporate service quality performance of design-build contractors using quality function deployment', Construction Management and Economics, 21(2), 175-185.

ABS (2007) Construction work done, December Quarter, Cat. No. 8275.0, Chart 5, Canberra: Australian Bureau of Statistics.

Barlow, J. and Jashapara, A. (1998) 'Organisational learning and inter-firm partnering in the UK construction industry', The Learning Organisation, 5(2), 86-98.

Bowley, M. (1996) The British building industry, London: Cambridge University Press.

Bresnen, M. and Marshall, N. (2000) 'Partnering in construction: A critical review of issues, problems and dilemmas', Construction Management and Economics, 18(2), 229-237.

Cartlidge, D.P. (2004) Procurement of built assets, Oxford: Elsevier Butterworth-Heinemann.

Chan, A.P.C., Chan, D.W.M. and Ho, K.S.K. (2003) 'An empirical study of the benefits of construction partnering in Hong Kong', Construction Management and Economics, 21(5), 523-533.

Coffey, V. (2008) 'Measuring quality: How does this improve construction performance', in proceedings of 2008 CIB International Conference on Building Education and Research, Sri Lanka.

Cox, I.D., Morris, J.P., Rogerson, J.H. and Jared, G.E. (1999) 'A quantitative study of post contract award design changes in construction', Construction Management and Economics, 17(4), 427-439.
Dulaimi, M.F. (2005) 'The challenge of customer orientation in the construction industry', Construction Innovation, 5(1), 3-4.

Fong, P.S. and Choi, S.K. (2000) 'Final contractor selection using analytical hierarchy process', Construction Management and Economics, 18(5), 547-557.

Hall, K.A. and Pearl, R.G. (2002) 'Perceptions of time, cost and quality management on building projects', Australian Journal of Construction Economics and Building, 2(2), 48-56.

Hampson, K. (2005) 'Collaboration and innovation in property and construction', Building Economist, March, 4.

Hatush, Z. and Skitmore, M. (1997) 'Criteria for contractor selection', Construction Management and Economics, 15(2), 1938

Kumaraswamy, M. and Dulaimi, M. (2001) 'Empowering innovative improvements through creative construction procurement', Engineering, Construction and Architectural Management, 8(5), 325-334.

Langford, D., Martines, V. and Bititci, U. (2007) 'Best value in construction: Towards an interpretation of value from client and constructor perspectives', Journal of Construction Procurement, 9(1), 56-67.

London, K., Chen, J. and Bavinton, N. (2005) 'Adopting reflexive capability in international briefing', Facilities, 23(7), 295-318.

Love, P.E.D., Mandal, P. and Li, H. (1999) 'Determining the causal structure of rework influences in construction', Construction Management and Economics, 17(4), 505-517.

Mahdi, I.M., Riley, M.J., Fereig, S.M. and Alex, A.P. (2002) 'A multicriteria approach to contractor selection', Engineering Construction and Architectural Management, 9(1), 29-37.

Manley, K. (2006) 'The innovation competence of repeat public sector clients in the Australian construction industry', Construction Management and Economics, 24(2), 1295-1304.

Masterman, J.W.E. (2002) The selection of procurement systems, London: E. \& F.N. Spon.

Nam, C.H. and Tatum, C.B. (1992) 'Strategies for technology push: Lessons from construction innovations', Journal of Construction Engineering and Management, 118(3), 507-521.

Ng, T.S., Skitmore, R.M., and Smith, N.J. (1999) 'Decision makers' perception in the formulation of prequalification criteria', Engineering Construction and Architectural Management, 6(2), $155-165$

Palaneeswaran, E. and Kumaraswamy, M.M. (2001) 'Recent advances and proposed improvements in contractor prequalification methodologies', Building and Environment, 36(1), 73-87.

Rowlinson, S. and McDermott, P. (1999) Procurement systems: A guide to best practice in construction, E. \& F.N. Spon, London.

Sidwell, A. C., Budiawan, D. and Ma, T. (2001) 'The significance of the tendering contract on the opportunities for clients to encourage contractor-led innovation', Construction Innovation, 1(2), 107-116. 
Slaughter, E.S. (1998) 'Models of construction innovation', Journal of Construction Engineering and Management, 124(3), 226-231.

Smith, J., Wyatt, R. and Love, P.E.D. (2008) 'Key decision-making attributes for project inception', Facilities, 26(7/8), 289-309.

Soetanto, R. and Proverbs, D.G. (2002) 'Modelling the satisfaction of contractors: The impact of client performance', Engineering Construction and Architectural Management, 9(5/6), 453-465.

Uher, T.E. (1999) 'Partnering performance in Australia', Journal of Construction Procurement, 5(2).

Walker, D.H.T. and Hampson, K. (2003) Procurement strategies: A relationship-based approach, Oxford: Blackwell Science.

Walker, D.H.T., Hampson, K.D. and Ashton, S. (2003) ‘Developing an innovative culture through relationship-based procurement systems' in Procurement strategies, D.H.T. Walker and K.D. Hampson, eds., Oxford: Blackwell.

Yates, J.K. and Battersby, L.C. (2003) "Master builder project delivery system and designer construction knowledge', Journal of Construction Engineering and Management.

Yu, A.T.W., Shen, Q., Kelly, J. and Hunter, K. (2008) 'Comparative study of the variables in construction project briefing/architectural programming', Journal of Construction Engineering and Management, 134(2), 122-138.

Zaghloul, R. and Hartman, F. (2006) 'Construction contracts: The cost of mistrust', International Journal of Project Management, 21(6), 419-424. 
[blank]

8 The Australasian Journal of Construction Economics and Building [Vol 9, № 1] 